\title{
Анализ равномерности заключения договоров на закупку товаров, работ, услуг у единственного поставщика бюджетной организации
}

\section{Л. С. Коробейникова ${ }^{1 凶}$}

${ }^{1}$ Воронежский государственный университет, Университетская пл., 1, 394018, Воронеж, Российская Федерация

Для цитирования: Коробейникова Л. С. Анализ равномерности заключения договоров на закупку товаров, работ, услуг у единственного поставщика бюджетной организации // Вестник Воронежского государственного университета. Серия: Экономика и управление. 2020. № 2. C. 55-65. DOI: 10.17308/econ.2020.2/2901

\begin{abstract}
Предмет. Проблема применения неконкурентных способов определения поставщика, подрядчика, исполнителя в рамках осуществления закупочной деятельности образовательной организации волнует многих субъектов контрактной системы РФ от самих заказчиков до контрольных органов, занимающихся регулированием закупочной деятельности и соблюдением законодательства в сфере закупки товаров, работ, услуг. Осуществление закупки у единственного поставщика нарушает реализацию отдельных принципов функционирования контрактной системы, способствует ограничению информационной базы экономического анализа эффективности закупки, способствует неравномерности распределения финансовых ресурсов для покрытия обязательств по исполнению договорных обязательств.
\end{abstract}

Цели. Комплексное авторское исследование анализа равномерности заключения договоров на закупку товаров, работ, услуг у единственного поставщика бюджетной образовательной организации. Разработка системы показателей экономического анализа равномерности заключения договоров, которая позволит ускорить оборачиваемость товаров, работ, услуг, улучшить качество закупки товаров, работ, услуг и мобилизации внутренних резервов финансирования закупки.

Методология. В процессе исследования проблемы применялись такие общенаучные методы познания, как анализ и синтез, системность и комплексность, использовались логический подход к получению доказательств и аргументация новых положений экономического анализа.

Результаты. Использование экстенсивного пути удовлетворения потребности заказчика в товарах, работах, услугах ведет к росту затратоемкости заключения договоров на закупку товаров, работ, услуг у единственного поставщика. Экономное использование товаров, рациональность закупки работ, услуг, обоснованность расчета начальной (максимальной) цены договора - цены договора с единственным поставщиком способствуют росту объемов закупочной деятельности и рентабельности затрат на ее осуществление.

Выводы. Расчет и интерпретация значений показателей анализа равномерности заключения и исполнения договоров на закупку товаров, работ, услуг у единственного поставщика позволят выработать рекомендации заказчику в области соблюдения принципа равномерности распределения финансовых ресурсов и формирования положений основных локальных финансовых документов образовательного учреждения, направленных на повышение результативности закупочной деятельности экономических субъектов.

Ключевые слова: равномерность, договор, единственный поставщик, закупка, план-график.

\section{Введение}

Необходимым условием исполнения плана-графика закупки товаров, работ, услуг, снижения затратоемкости подготовки документации для проведения закупки, роста экономии в рамках применения конкурентных способов определения поставщика, под-

(C) Коробейникова Л. С., 2020

Вестник ВГУ. Серия: Экономика и управление. 2020. № 2. С. 55-65. рядчика, исполнителя, рентабельности закупки товаров, работ, услуг выступает полное и своевременное обеспечение нужд экономического субъекта товарами, работами, услугами необходимого ассортимента и качества, рациональное их использование в научно-образовательных процессах деятельности образовательных учреждений. 
Развитие контрактной системы РФ, реализация основных положений дорожной карты функционирования Федеральной антимонопольной службы связаны с вопросами обоснования выбора способа определения поставщика, подрядчика, исполнителя в рамках удовлетворения потребности экономического субъекта (заказчика) в закупке товаров, работ, услуг [14]. В практической деятельности заказчики наиболее часто прибегают к использованию неконкурентных способов определения поставщика, подрядчика, исполнителя, а именно к осуществлению закупки у единственного поставщика [2]. По мнению заказчиков, использование данного способа закупки товаров, работ, услуг позволяет существенно экономить время подготовки документации по закупке (проекта договора, технического задания, спецификаций) с указанием конкретных требований к закупаемым предметам закупки, что снижает трудоемкость подготовки документации по закупке, повышает качество поставленного товара, оказанной услуги, выполненных работ. В то же время законодательство в сфере реализации основных положений контрактной системы РФ уделяет существенное внимание реализации в действии принципов свободной конкуренции и экономичности осуществления закупки [3]. Мы понимаем, что применение заказчиками неконкурентных способов определения поставщика, подрядчика, исполнителя не позволяет участвовать в закупке неограниченному количеству участников, что нарушает условия свободной конкуренции и оптимального ценообразования, направленного на получение экономического эффекта путем снижения начальной (максимальной) цены договора [18]. Законодательно установлен перечень объектов и условий закупки товаров, работ, услуг, которые могут быть «закуплены» в условиях заключения договоров у единственного поставщика. Следует помнить, что контрольные органы в сфере закупки товаров, работ, услуг оценивают обоснованность выбора неконкурентного способа определения поставщика, подрядчика, исполнителя [9].

В ходе проведения экономического анализа обоснованности и целесообразности использования неконкурентного способа определения поставщика, подрядчика, исполнителя как «закупки у единственного поставщика» необходимо выделить основные направления анализа:

- анализ обоснованности выбора данного способа определения поставщика, подрядчика, исполнителя;

- анализ достоверности применения различных способов ценообразования в рамках расчета обоснованности начальной (максимальной) цены договора, учитывая, что в условиях заключения договора у единственного поставщика невозможно снижение цены и договор будет заключен на основе расчета данного показателя;

- анализ равномерности заключения договоров на закупку товаров, работ, услуг у единственного поставщика, что позволит соблюдать принцип равномерности распределения финансовых ресурсов при формировании плана финансово-хозяйственной деятельности учреждения, плана-графика закупок товаров, работ, услуг.

Существенное внимание в ходе экономического анализа следует уделять анализу равномерности заключения договоров на закупку товаров, работ, услуг у единственного поставщика.

\section{Информационная база анализа}

Информационная база анализа заключения договоров на закупку товаров, работ, услуг у единственного поставщика включает [15]:

- законодательные и нормативные акты в области функционирования контрактной системы РФ;

- учетную политику экономического субъекта (заказчика) [4];

- утвержденный порядок формирования начальной (максимальной) цены договора (НМЦК) (если имеет место);

- планы-графики закупок товаров, работ, услуг на соответствующие финансовые периоды;

- реестр договоров, в том числе копии заключенных договоров с исполнительной документацией (акты выполненных работ, накладные, счета-фактуры, платежные поручения);

- отчеты об исполнении договоров или результатах исполнения отдельных этапов договора.

Следует понимать, что в условиях функционирования контрактной системы РФ информация о заключении и исполнении договоров размещается в единой информационной си- 
Анализ равномерности заключения договоров на закупку товаров, работ, услуг...

стеме (далее - ЕИС) [19-21], однако в условиях заключения договоров у единственного поставщика информация, размещаемая в ЕИС, крайне ограничена. В плане-графике закупок товаров, работ, услуг планируемые закупки у единственного поставщика не выделяются по отдельным позициям, представлены обобщенно по направлениям бюджетной классификации расходов. Для аналитика эта информация будет закрыта отсутствием детализации при планировании [5; 11]. Кроме того,данные виды договоров не включаются в электронный реестр контрактов (договоров), что ограничивает возможности ЕИС для проведения анализа заключения и исполнения договоров у единственного поставщика.

\section{Обсуждение результатов}

Особое внимание при проведении анализа закупки товаров, работ, услуг следует уделять анализу равномерности заключения договоров у единственного поставщика. Под равномерностью мы предлагаем понимать заключение объемов договоров на закупку товаров, работ, услуг у единственного поставщика в равных долях от общего объема в одинаковые промежутки времени в соответствии с разработанным планом-графиком закупок товаров, работ, услуг в установленном объеме [10; 12].

Анализ равномерности заключения договоров на закупку товаров, работ, услуг у единственного поставщика следует начать с анализа количественной структуры заключенных договоров в рамках закупки у единственного поставщика по квартальным периодам года [7] (табл. 1).

Данные табл. 1 показывают, что у исследуемой организации сложились устойчивые тенденции неравномерной работы по заключению договоров у единственного поставщика. Наиболее интенсивным периодом можно считать последний квартальный период года, на который приходится наибольший количественный объем заключенных договоров заказчика. Их доля выше 30 \%, а в отчетном периоде этот показатель вырос на 3,26 \%. В ходе анализа было выявлено, что низкий уровень заключения договоров в первом квартальном периоде обусловлен спецификой функционирования образовательной организации высшего образования. В первом квартальном периоде проходит утверждение Плана ФХД, плана-графика закупки товаров, работ, услуг, что не позволяет осуществлять закупочную деятельность в январе отчетного периода [1]. Отметим, что образовательные организации имеют также каникулы в образовательном процессе, что снижает равномерность осуществления закупочного процесса в первом и третьем квартальном периоде.

Сложившиеся тенденции в организации неравномерного процесса закупки товаров, работ, услуг у единственного поставщика в отчетном периоде представлены на рис. 1. Неравномерность повышает трудоемкость работы специалистов службы закупок в четвертом квартальном периоде, способствует формированию резервов денежных средств для осуществления оплаты исполнения заключенных договоров на конец календарного года, что повышает неравномерность платежной дисциплины и концентрацию наибольших платежей в конце отчетного периода.

Проведем анализ равномерности заключения договоров по стоимостному объему заключенных договоров по квартальным периодам

Т а блица 1

Анализ объема и структуры количества заключенных договоров в рамках закупки у единственного поставщика, подрядчика, исполнителя

\begin{tabular}{|c|c|c|c|c|c|c|}
\hline \multirow{3}{*}{ Период } & \multicolumn{6}{|c|}{$\begin{array}{c}\text { Объем договоров, заключенных за 2018-2019 гг. за счет средств грантов; средств, } \\
\text { предоставленных в рамках исполнения контрактов; средств, полученных при осущест- } \\
\text { влении иной приносящей доход деятельности от физических и юридических лиц }\end{array}$} \\
\hline & \multicolumn{2}{|c|}{ количество, шт. } & \multirow{2}{*}{$\begin{array}{c}\text { абсолютное } \\
\text { изменение, шт. }(+,-)\end{array}$} & \multicolumn{2}{|c|}{ удельный вес к итогу, \% } & \multirow{2}{*}{$\begin{array}{l}\text { изменения удель- } \\
\text { ного веса, пункты }\end{array}$} \\
\hline & 2018 г. & 2019 г. & & 2018 г. & 2019 г. & \\
\hline І квартал & 299 & 222 & -77 & 15,44 & 14,74 & $-0,70$ \\
\hline II квартал & 599 & 451 & -148 & 30,94 & 29,95 & $-0,99$ \\
\hline III квартал & 416 & 300 & -116 & 21,49 & 19,92 & $-1,57$ \\
\hline IV квартал & 622 & 533 & -89 & 32,13 & 35,39 & $+3,26$ \\
\hline Итого & 1936 & 1506 & -430 & 100,00 & 100,00 & - \\
\hline
\end{tabular}




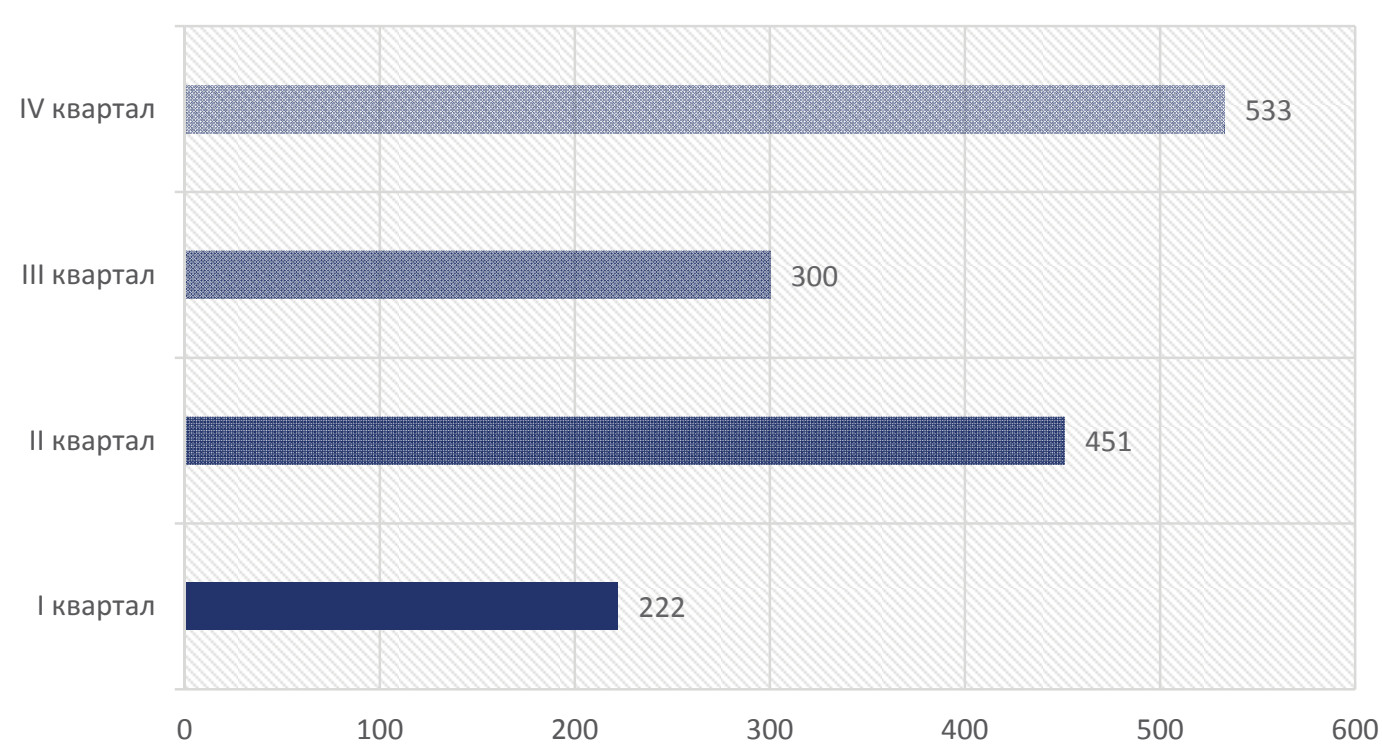

Puc. 1. Анализ структуры договоров, заключенных в рамках закупки у единственного поставщика, шт.

года [7]. По данным табл. 2 отметим [13; 16-17], что стоимость заключенных договоров на закупку товаров, работ, услуг у единственного поставщика составляет 102 653,61 тыс. руб., что преимущественно приходится на закупки IV квартального периода 2019 г. (удельный вес - 61,74 \%). Данная тенденция сохранялась и в предыдущем периоде, удельный вес заключения договоров в стоимостном выражении приходится на IV квартальный период 2018 г. и составляет $43,84 \%$.

Данные табл. 2 показывают, что превышение ежеквартального значения равномерности заключения договоров на закупку товаров, работ, услуг составляет 18,84 \%. Значение данного показателя в 2019 г. по сравнению с ежеквартальным значением закупки в IV квартальном периоде 2018 г. выросло на 17,91 \%. Отметим, что в отчетном периоде соблюдение условий равномерности заключения договоров на закупку товаров, работ, услуг не выполняется: произошел существенный рост удельного веса заключения договоров в IV квартальном периоде; удельный вес стоимостного объема заключенных договоров по остальным квартальным периодам сократился по сравнению с предыдущим периодом.

Рисунок 2 подтверждает данные табл. 2, что по стоимости заключенных договоров в рамках закупки у единственного поставщика неравномерность осуществления закупки существенно нарушена. На первый квартальный период 2019 г. приходится 5,63 \% от объема закупки у единственного поставщика. Отметим, что по сравнению с 2018 г. указанный показатель сократился на 7,3 \%. Существенным нарушением условия равномерности является и удельный вес закупки товаров, работ, услуг в IV кварталь-

Т а бл и ц 2

Анализ объема и структуры заключенных договоров

в рамках закупки у единственного поставщика, подрядчика, исполнителя

\begin{tabular}{|c|c|c|c|c|c|c|}
\hline \multirow[t]{3}{*}{ Период } & \multicolumn{6}{|c|}{$\begin{array}{c}\text { Объем договоров, заключенных за 2018-2019 гг. за счет средств грантов; средств, } \\
\text { предоставленных в рамках исполнения контрактов; средств, полученных при осущест- } \\
\text { влении иной приносящей доход деятельности от физических и юридических лиц }\end{array}$} \\
\hline & \multicolumn{2}{|c|}{ стоимость, тыс. руб. } & \multirow{2}{*}{$\begin{array}{c}\text { абсолютное измене- } \\
\text { ние, тыс. руб. }(+,-)\end{array}$} & \multicolumn{2}{|c|}{ удельный вес к итогу, \% } & \multirow{2}{*}{$\begin{array}{l}\text { изменения удель- } \\
\text { ного веса, пункты }\end{array}$} \\
\hline & 2018 г. & 2019 г. & & 2018 г. & 2019 г. & \\
\hline І квартал & 20026,32 & 9364,51 & $-10661,81$ & 12,93 & 5,63 & $-7,30$ \\
\hline II квартал & 29573,70 & 23429,37 & & 19, & 14 & -5 \\
\hline III квартал & 37392,51 & 308 & & 24 & 18 & \\
\hline IV квартал & 67895,20 & 102653,61 & $+34758,41$ & 43,84 & 61,74 & $+17,91$ \\
\hline Итого & 154887,73 & 166263,25 & 11375,52 & 100,0 & 100,0 & - \\
\hline
\end{tabular}




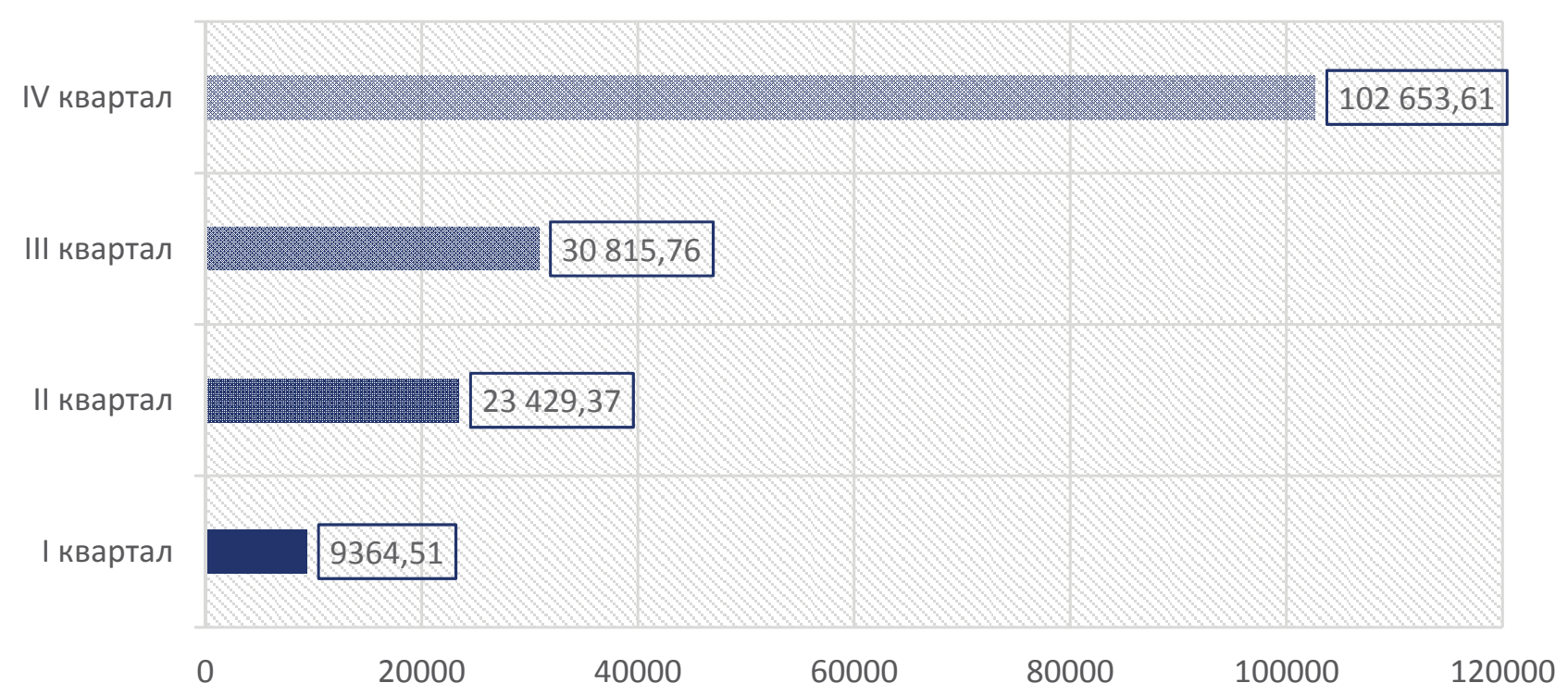

Puc. 2. Анализ структуры договоров, заключенных в рамках закупки у единственного поставщика

ном периоде 2019 г. При условии соблюдения равномерного условия осуществления закупки товаров, работ, услуг по квартальным периодам нарушение равномерности составляет 36,74 \%.

Равномерное заключение договоров в рамках закупки у единственного поставщика позволит экономическому субъекту контролировать сроки заключения и исполнения договорных обязательств согласно утвержденному плану-графику закупки товаров, работ, услуг на условиях равномерности заключения договоров, что приведет к ускорению оборачиваемости товаров, работ, услуг, сокращению остатков и улучшению «качества» закупки.

Для оценки выполнения планового задания по равномерности заключения договоров с единственным поставщиком рекомендуем использовать следующие показатели [10]: коэффициент равномерности; коэффициент вариации; коэффициент неравномерности; удельный вес договоров, заключенных с единственным поставщиком за каждую декаду, к объему договоров, заключенных с единственным поставщиком за месяц; удельный вес договоров, заключенных с единственным поставщиком за каждый месяц, к квартальному объему договоров, заключенных с единственным поставщиком; удельный вес договоров, заключенных с единственным поставщиком за каждый квартал, к годовому объему договоров, заключенных с единственным поставщиком.

Наибольшее внимание, по нашему мнению, необходимо уделить расчету показателя «равномерность заключения договоров на закупку товаров, работ, услуг у единственного поставщика» [12]. Коэффициент равномерности определяется делением суммы заключенных договоров, которая зачтена в выполнение условий равномерности заключения, на объем заключенных договоров согласно условиям равномерного заключения по следующей формуле:

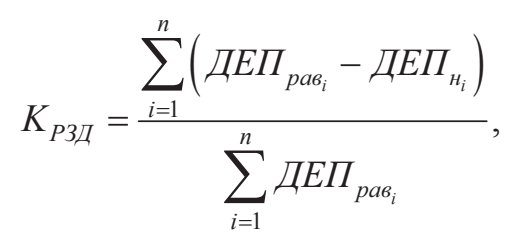

где $K_{\text {Рзд }}$ коэффициент равномерности заключения договоров; ДЕП рав $_{i}-$ объем договоров, заключенных на закупку товаров, работ, услуг у единственного поставщика за $i$-е периоды при условии равномерного заключения договоров, тыс. р.; ДЕП н $_{i}$ - недозаключение объема договоров с единственным поставщиком за $i$-е периоды при условии равномерного заключения договоров, тыс. p.

Проведем анализ равномерности заключения договоров на закупку товаров, работ, услуг у единственного поставщика путем расчета указанного коэффициента (табл. 3).

Согласно данным табл. 3 коэффициент равномерности составляет

$$
K_{\text {Рзд }}=\frac{105175,45}{166263,25}=0,6326 .
$$

Бюджетная образовательная организация достаточно неравномерно осуществляет за- 
Анализ равномерности заключения договоров на закупку товаров, работ, услуг у единственного поставщика по квартальным периодам

\begin{tabular}{|c|c|c|c|c|c|c|}
\hline \multirow[b]{2}{*}{ Период } & \multicolumn{2}{|c|}{$\begin{array}{l}\text { Объем договоров, заклю- } \\
\text { ченных за } 2019 \text { г., тыс. р. }\end{array}$} & \multicolumn{2}{|c|}{ Удельный вес, \% } & \multirow{2}{*}{$\begin{array}{c}\text { Выполнение } \\
\text { условий рав- } \\
\text { номерности, } \\
\text { коэффициент }\end{array}$} & \multirow{2}{*}{$\begin{array}{c}\text { Объем заключенных } \\
\text { договоров, зачтен- } \\
\text { ных в выполнение } \\
\text { условий равномер- } \\
\text { ности заключения, } \\
\text { тыс. р. }\end{array}$} \\
\hline & $\begin{array}{c}\text { факти- } \\
\text { чески }\end{array}$ & $\begin{array}{c}\text { при условии } \\
\text { равномерного } \\
\text { заключения }\end{array}$ & $\begin{array}{c}\text { факти- } \\
\text { чески }\end{array}$ & $\begin{array}{c}\text { при усло- } \\
\text { вии рав- } \\
\text { номерного } \\
\text { заключения }\end{array}$ & & \\
\hline I квартал & 9364,51 & 41565,81 & 5,63 & 25,0 & 0,2253 & 9364,51 \\
\hline II квартал & 23429,37 & 41565,81 & 14,09 & 25,0 & 0,5637 & 23429,37 \\
\hline III квартал & 30815,76 & 41565,81 & 18,53 & 25,0 & 0,7414 & 30815,76 \\
\hline IV квартал & 102653,61 & 41565,81 & 61,74 & 25,0 & 2,4697 & 41565,81 \\
\hline $\begin{array}{l}\text { Всего за от- } \\
\text { четный год }\end{array}$ & 166263,25 & 166263,25 & 100,0 & 100,0 & 1,0000 & 105175,45 \\
\hline
\end{tabular}

ключение договоров на закупку товаров, работ, услуг у единственного поставщика по квартальным периодам в отчетном периоде. Отметим, что данная динамика прослеживается из периода в период осуществления закупочной деятельности. Наибольший удельный вес от общего объема заключенных договоров приходится на последний квартал $-61,74$ \%. При этом наблюдается невысокая активность заключения договоров в первом квартальном периоде года - 5,63 \% от общего объема договоров, заключенных на закупку товаров, работ, услуг у единственного поставщика за годовой период. Данные расчеты дополняются невысокими значениями коэффициентов выполнения условий равномерности заключения договоров на закупку товаров, работ, услуг у единственного поставщика за первый квартальный период года. В целом процесс заключения договоров на закупку товаров, работ, услуг у единственного поставщика нельзя считать равномерным.

Для оценки неравномерности заключения договоров рекомендуем использовать коэффициент вариации как отношение среднеквадратического отклонения от объема при условии равномерного заключения договоров за сутки (декаду, месяц, квартал) к среднесуточному (среднедекадному, среднемесячному, среднеквартальному) объему заключенных договоров согласно условиям равномерного заключения:

$$
K_{B}=\frac{\sqrt{\sum_{i=1}^{n} \frac{\Delta Д E \Pi^{2}}{n}}}{\overline{Д E \Pi}_{p a s}},
$$

где $\triangle Д Е \Pi^{2}$ - квадрат отклонения от среднеквартального значения; $n$ - число суммируемых временных периода; $\overline{Д Е П}_{\text {рав }}-$ среднеквартальное значение по плану-графику закупки товаров, работ, услуг у единственного поставщика.

Коэффициент неравномерности также рекомендуем использовать в процессе анализа равномерности заключения договоров на закупку товаров, работ, услуг у единственного поставщика как характеризующий степень отклонения от равномерного графика заключения договоров. Данный коэффициент определяется по следующей формуле:

$$
K_{H E P}=\sqrt{\frac{\sum(\alpha-100)^{2} \times \gamma}{\sum \gamma}},
$$

где $\alpha$ - процент выполнения условий равномерного заключения договоров, \%; $\gamma$ - вес группы, \%.

Проведя расчеты (табл. 4), мы получили значение коэффициента вариации на уровне 0,87 . Это значит, что объем заключенных договоров отклоняется от равномерного плана-графика закупки товаров, работ, услуг у единственного поставщика в среднем на $87 \%$. В исследуемой организации наметились устойчивые тенденции неравномерности заключения договоров на закупку товаров, работ, услуг у единственного поставщика. По нашему мнению, данное положение характеризует низкий уровень организации управления закупочной деятельностью, контроля допустимых объемов финансирования на конец отчетного периода и, как следствие, замедление оборачиваемости товаров, работ, услуг. 
Анализ равномерности заключения договоров на закупку товаров, работ, услуг...

Анализ неравномерности заключения договоров на закупку товаров, работ, услуг у единственного поставщика

\begin{tabular}{|c|c|c|c|c|}
\hline \multirow{2}{*}{ Период } & \multicolumn{2}{|c|}{$\begin{array}{c}\text { Объем договоров, } \\
\text { заключенных за } 2019 \text { г., тыс. p. }\end{array}$} & \multirow{2}{*}{$\begin{array}{c}\text { Отклонение от объема } \\
\text { договоров при условии } \\
\text { равномерного заключения }\end{array}$} & \multirow{2}{*}{$\begin{array}{l}\text { Квадрат суммы } \\
\text { отклонений }\end{array}$} \\
\hline & фактически & $\begin{array}{c}\text { при условии } \\
\text { равномерного } \\
\text { заключения }\end{array}$ & & \\
\hline I квартал & 9364,51 & 41565,81 & $-32201,30$ & 1036923721,69 \\
\hline II квартал & 23429,37 & 41565,81 & $-18136,44$ & 328930455,87 \\
\hline III квартал & 30815,76 & 41565,81 & $-10750,05$ & 115563575,01 \\
\hline IV квартал & 102653,61 & 41565,81 & 61087,80 & 3731719308,84 \\
\hline $\begin{array}{l}\text { Всего за } \\
\text { отчетный } \\
\text { год }\end{array}$ & 166263,25 & 166263,25 & - & 5213137061,56 \\
\hline
\end{tabular}

\begin{tabular}{|l|c|c|c|c|c|}
\hline \multicolumn{1}{|c|}{ Период } & $\begin{array}{c}\text { Выполне- } \\
\text { ние условий } \\
\text { равномерного } \\
\text { заключения, \% }\end{array}$ & $\begin{array}{c}\text { Отклонение фак- } \\
\text { тического уровня } \\
\text { оомернй рав- } \\
\text { номесл }\end{array}$ & $\begin{array}{c}\text { Вес } \\
\text { группы }\end{array}$ & $\begin{array}{c}\text { Квадрат отклоне- } \\
\text { ние фактического } \\
\text { уровня от условий } \\
\text { равномерности }\end{array}$ & $\begin{array}{c}\text { Квадрат отклонение } \\
\text { фактического уровня от } \\
\text { условий равномерности, } \\
\text { умноженный на вес }\end{array}$ \\
\hline I квартал & 22,53 & $-77,47$ & 415,66 & 6001,60 & 2494625,43 \\
\hline II квартал & 56,37 & $-43,63$ & 415,66 & 1903,58 & 791240,77 \\
\hline III квартал & 74,14 & $-25,86$ & 415,66 & 668,74 & 277968,30 \\
\hline IV квартал & 246,97 & 146,97 & 415,66 & 21600,18 & 8978331,19 \\
\hline $\begin{array}{l}\text { Всего за } \\
\text { отчетный } \\
\text { год }\end{array}$ & & & 1662,64 & & 12542165,70 \\
\hline
\end{tabular}

$$
\begin{gathered}
K_{B}=\frac{\sqrt{5213137061,56 / 4}}{41565,81}=0,87, \\
K_{H E P}=\sqrt{\frac{12542165,70}{1662,64}}=86,85 \% .
\end{gathered}
$$




\section{Заключение}

Рост потребности образовательной организации в товарах, работах, услугах может удовлетворяться на основе роста заключения договоров на закупку товаров, работ, услуг в количественном и стоимостном выражении, а также более экономного использования имеющихся запасов товаров, выполнения условий равномерного заключения и выполнения договоров на закупку товаров, работ, услуг, в том числе на основе рациональной комбинации конкурентных и неконкурентных способов определения поставщика, подрядчика, исполнителя.

В условиях предпочтения экономическим субъектом выбора неконкурентных способов определения поставщика, подрядчика, исполнителя необходимо помнить о целесообразности соблюдения заложенных пропорций в определении сумм расходов по отдельным направлениям расходов бюджетной классификации, зафиксированных заказчиком в плане-графике закупки товаров, работ, услуг на очередной финансовый год. Таким образом, для образовательной организации соблюдение данного условия также попадает под проверку государственных контрольных органов в сфере закупки товаров, работ, услуг, как и обоснованность выбора в качестве способа определения поставщика, подрядчика, исполнителя неконкурентного способа закупки [8].

Отметим, что в ходе анализа равномерности заключения договоров у единственного поставщика необходимо учитывать изменения, вносимые в общий объем закупки товаров, работ, услуг, при осуществлении плановых изменений плана-графика закупок. Изменение годового планируемого объема закупки товаров, работ, услуг приведет к изменению объема заключенных договоров на закупку товаров, работ, услуг у единственного поставщика при условии равномерного заключения договоров в рассматриваемый период.

Использование в качестве инструментария элементов коэффициентного анализа позво-

\section{Библиографический список}

1. Архипычева К. Л. Государственные закупки : учебное пособие для бакалавров направления 380301 «Экономика» / К. Л. Архипычева, А. В. Кривошеев, Л. С. Коробейникова. - Воронеж : Воронежский государственный университет, 2018. - 56 с. ляет оценить соблюдение условий равномерности расходования финансовых ресурсов, обосновать степень отклонения бюджетной организацией от равномерного графика заключения договоров, оценить уровень организации и управления закупочной деятельностью экономического субъекта. Реализация положений в области формирования равномерного графика заключения договоров позволит бюджетной организации снизить трудоемкость закупочной деятельности, повысить контроль исполнения условий договоров, в том числе и по срокам оплаты выполненных договорных условий [6]. Повышение качества платежной дисциплины и более равномерное распределение платежей по выполненным договорам внутри финансового периода позволит ускорить оборачиваемость активов образовательной организации, сократит остатки и повысит качество закупочной деятельности.

Необходимость соблюдения условий равномерности заключения договоров должна быть зафиксирована в локальных актах образовательной организации в сфере закупочной деятельности. Например, Положение о закупочной деятельности образовательной организации может включать обязательное соблюдение условия равномерности заключения договоров по отдельным квартальным периодам отчетного периода при осуществлении закупки товаров, работ, услуг у единственного поставщика. Равномерность распределения объемов закупаемых товаров, работ, услуг внутри квартальных периодов способствует равномерности формирования ежемесячной отчетной информации о количестве и стоимости заключенных договоров у единственного поставщика, размещаемой в ЕИС, что повышает качество планирования в сфере закупки.

\section{Конфликт интересов}

Авторы декларируют отсутствие явных и потенциальных конфликтов интересов, связанных с публикацией настоящей статьи.

2. Балаева О.Н. Во сколько обходятся госзакупки российскому заказчику? / О. Н. Балаева, Л. С. Коробейникова, Е. Е. Чупандина, А. А. Яковлев. // Госзаказ : управление, размещение, обеспечение. 2014. - № 36. - С. 72-81.

3. Балаева О. Н. Эмпирический анализ систем госзакупок в России / О. Н. Балаева, А. А. Бальсевич, 
Анализ равномерности заключения договоров на закупку товаров, работ, услуг...

А. С. Башина. - Москва : Издательский дом Высшей школы экономики, 2015. - 357 с.

4. Бухгалтерский учет и отчетность : учебное пособие / Н. Г. Сапожникова, И. В. Панина, О.Н. Гальчина, Л. С. Коробейникова ; [под ред. Д. А. Ендовицкого]. - Москва : КНОРУС, 2015. - 360 с.

5. Володина М. С. Анализ взаимодействия субъектов контрактной системы в области управления закупками / М. С. Володина, Л. С. Коробейникова // Современная экономика: проблемы и решения. 2016. - № 4. - C. 93-102.

6. Вызовы современности : проблемы, возможности, решения : монография / Е. И. Костюкова [и др.] ; [под общ. ред. Е. И. Костюковой]. - Ставрополь : АГРУС Ставропольского гос. аграрного ун-та, 2015. - 136 с.

7. Годовой отчет ВГУ. - URL: http://www.vsu.ru/ ru/university/docs/report2018.pdf\#2

8. Головин С. В. Осуществление контроля в сфере закупок в государственных медицинских организациях / С. В. Головин // Современная экономика : проблемы и решения. - 2018. - № 4 (100). - С. 95-101.

9. Ендовицкий Д. А. Анализ состава, структуры и равномерности обоснования способа определения поставщика (подрядчика, исполнителя) / Д. А. Ендовицкий, К. Л. Канина // Современная экономика : проблемы и решения. - 2017. - № 2 (86). - C. 16-25.

10. Ендовицкий Д. А. Экономический анализ задолженности по векселям: учебное пособие / Д. А. Ендовицкий, Л. С. Коробейникова ; [под ред. Д. А. Ендовицкого]. - Москва : Финансы и статистика, 2005. - 272 с.

11. Когденко Г. В. Методика анализа распределительной политики компании / Г. В. Когденко // Международный бухгалтерский учет. - 2017. - Т. 20. № 16. - С. 948-961.

12. Коробейникова Л. С. Анализ объема, качества и структуры вексельной задолженности коммерческой организации / Л. С. Коробейникова, Д. В. Титов // Современная экономика : проблемы и решения. - 2010. - № 2. - С. 109-127.

13. Коробейникова Л. С. Анализ результативности закупочной деятельности образовательной организации / Л. С. Коробейникова, Н. В. Кондрашова // Актуальные проблемы учета, экономического анализа и финансово-хозяйственного кон- троля деятельности организаций : материалы Второй Междунар. заоч. науч.-практ. конференции. - Воронеж, 2015. - Ч. 2. - С. 81-84.

14. Коробейникова Л. С. Анализ результативности закупочной деятельности образовательной организации / Л. С. Коробейникова, Н. В. Кондрашова // Актуальные проблемы учета, экономического анализа и финансово-хозяйственного контроля деятельности организаций : материалы Второй Междунар. заоч. науч.-практ. конф. - Воронеж, 2015. - Ч. 2. - С. 81-84.

15. Коробейникова Л. С. Анализ результативности закупочной деятельности в рамках обоснования способов определения поставщиков (подрядчиков, исполнителей) / Л. С. Коробейникова // Финансовый вестник - 2016. - № 2 (33). - С. 109-117.

16. Мельник М. В. Экономический анализ в аудите : учебное пособие / М. В. Мельник, В. Г. Когденко. - Москва : ЮНИТИ-ДАНА, 2007. - 543 с.

17. Пласкова Н. С. Стратегический экономический анализ результативности бизнеса : монография / Н. С. Пласкова. - Москва : Изд-во Рос. гос. торг.-экон. ун-та, 2009. - 259 с.

18. Прокопчук Г. В. Анализ подходов к оценке эффективности размещения заказов бюджетной организации / Г. В. Прокопчук, Л. С. Коробейникова // Апрельские научные чтения имени профессора Л. Т. Гиляровской : материалы III Междунар. науч.-практ. конф., Воронеж, 25 апреля 2014 г.: в 2 ч. - Воронеж : Типография Воронежского ЦНТИ - филиала ФГБУ «РЭА» Минэнерго России, 2014. - С. 212-215.

19. Чупандина Е. Е. Информационное обеспечение экономического анализа закупки лекарственных препаратов/ Е. Е. Чупандина, Н. П. Ивановская // Современная экономика : проблемы и решения. - 2018. - № 4 (100). - С. 54-61.

20. Экономический анализ расчетов корпораций : учебное пособие / Д. А. Ендовицкий, Л. С. Коробейникова, И. В. Полухина ; [под ред. Д. А. Ендовицкого]. - Воронеж : Издательский дом ВГУ, 2017. - 246 с.

21.Эмпирический анализ систем госзакупок в России : монография / О.Н. Балаева, А. А. Бальсевич, А. С. Башина и др. ; [под общ. ред. А. А. Яковлева, О. А. Демидовой, Е. А. Подколзиной ; Нац. исслед. ун-т «Высшая школа экономики»]. - Москва : Издательский дом ВШЭ, 2015. - 357 с.
Лариса Сергеевна Коробейникова, кандидат экономических наук, доцент, заведующий кафедрой экономического анализа и аудита, Воронежский государственный университет, Воронеж, Российская Федерация

E-mail: korobeinikova@vsu.ru

ORCID ID: 0000-0003-4290-9880
Поступила в редакщию 20.04.2020

Подписана в печать 13.05.2020 


\section{Analysis of the uniform conclusion of agreements for the purchase of goods, works, services by a budgetary organization with a single supplier}

\section{S. Korobeinikova ${ }^{1 凶}$}

${ }^{1}$ Voronezh State University, 1, University sq., 394018, Voronezh, Russian Federation

Cite as: Korobeinikova, L. S. (2020). Analysis of the uniform conclusion of agreements for the purchase of goods, works, services by a budgetary organization with a single supplier. Proceedings of Voronezh State University. Series: Economics and Management. 2, 55-65. (In Russ., abstract in Eng.) DOI: 10.17308/ econ.2020.2/2901

Importance. The problem of using non-competitive methods of determining a supplier, contractor, performer in the framework of the procurement activities of an educational organization worries various subjects of the contract system of the Russian Federation, from customers to control bodies involved in the regulation of procurement activities and compliance with legislation in the field of procurement of goods, works, services. Making purchases from a single supplier violates the implementation of certain principles of the contract system, contributes to the limitation of the information base of the economic analysis of the procurement efficiency, contributes to the uneven distribution of financial resources to cover obligations to fulfill contractual obligations.

Objectives. The presented study is devoted to the analysis of the uniformity of the conclusion of contracts for the purchase of goods, works, services from a single supplier of a budgetary educational organization. The author paid considerable attention to the development of a system of indicators of economic analysis of the uniformity of the conclusion of contracts, which will accelerate the turnover of goods, works, services, improve the quality of the procurement of goods, works, services and mobilize internal reserves for financing procurement.

Methods. In the course of the study, the author used such general scientific methods of cognition as analysis and synthesis, consistency and complexity, as well as a logical approach to obtaining evidence and argumentation of new provisions of economic analysis.

Results. An extensive way of satisfying the customer's need for goods, works, services leads to an increase in the cost of concluding contracts for the purchase of goods, works, services from a single supplier. Which seems to confirm the idea that the economical use of goods, the rationality of the procurement of works and services, the validity of calculating the initial (maximum) price of the contract with a single supplier contribute to an increase in procurement and the profitability of costs for its implementation.

Conclusions and Relevance. From these facts, one may conclude that the calculation and interpretation of the values of the indicators of the analysis of the uniformity of the conclusion and execution of contracts for the purchase of goods, works, services from a single supplier will make it possible to develop recommendations for the customer in the field of observing the principle of uniform distribution of financial resources and the formation of provisions of the main local financial documents of an educational institution aimed at increasing the effectiveness of economic procurement activities.

Key words: uniformity, contract, single supplier, purchase, schedule.

\section{Conflict of Interest}

The authors declare that there are no obvious or potential conflicts of interest associated with the publication of this article. 
Analysis of the uniform conclusion of agreements for the purchase of goods, works, services...

\section{References}

1. Arkhipycheva, K. L., Krivosheev, A. V. \& Korobeinikova, L. S. (2018) Gosudarstvennye zakupki. Voronezh. Voronezh. St. Univ. Publ. (In Russ.)

2. Balaeva, O. N., Korobeinikova, L. S., Chupandina, E. E. \& Yakovlev, A. A. (2014) Vo skol'ko obkhodyatsya goszakupki Rossiiskomu zakazchiku? Goszakaz: upravlenie, razmeshchenie, obespechenie, 36, 72-81. (In Russ.)

3. Balaeva, O. N., Balsevich, A. A. \& Bashina, A. S. (2015) Empiricheskii analiz sistem goszakupokv Rossii. Moscow, HSE Publ. (In Russ.)

4. Endovitsky, D. A. (ed.) (2015) Accounting and reporting. Moscow. KNORUS. (In Russ.)

5. Volodina, M. S. \& Korobeinikova, L. S. (2016) Analysis of interaction between subjects of contract system in procurement management. Modern Economics: Problems and Solutions, 4, 93-102. (In Russ.)

6. Kostyukova, E. I. (ed.) (2015) Vyzovy sovremennosti: problemy, vozmozhnosti, resheniya. Stavropol, Stavropol. St. Agrarian Univ. Publ. (In Russ.)

7. Annual Report of Voronezh State University. URL: http://www.vsu.ru/ru/university/docs/report2018.pdf

8. Golovin, S. V. (2018) Control of procurement for provisioning state-owned healthcare organizations. Modern Economics: Problems and Solutions, 4, 95-101. (In Russ.)

9. Endovitsky, D. A. \& Kanina K. L. (2017) Analysis of the composition, structure and uniformity justification of the method of definition supplier (contractor, executor). Modern Economics: Problems and Solutions, 2, 16-25. (In Russ.)

10. Endovitsky, D. A. \& Korobeinikova, L. S. (2005) Ekonomicheskii analiz zadolzhennosti po vekselyam. Moscow. Finansy i statistika Publ. (In Russ.)

11. Kogdenko, V. G. (2017) A method to analyze the corporate payout policy. International Accounting, 20(16), 948-961. (In Russ.)

12. Korobeinikova, L. S. \& Titov, D. V. (2010) Analysis of the amount, quality and structure of bill indebtedness of a commercial organization. Modern Economics: Problems and Solutions, 2, 109-127. (In Russ.)

13. Korobeinikova, L. S. \& Kondrashova, N. V. (2015) Analiz rezultativnosti zakupochnoi deyatelnosti obrazovatelnoi organizatsii. Proceedings of International Conference "Actual problems of accounting, economic analysis and financial and economic control of organizations". Voronezh, pp. 81-84. (In Russ.)

14. Korobeinikova, L. S. (2016) Analysis of the procurement activity in the study ways particular vendor (contractors, performens). Financial Herald, 2(33), 109-117. (In Russ.)

15. Korobeinikova, L. S. (2020) Organizatsiya kompleksnogo ekonomicheskogo analiza zakupki tovarov, rabot, uslug ekonomicheskogo subyekta. Proceedings of International Conference "Actual problems and prospects for the development of audit, accounting, economic analysis and taxation”. Voronezh, pp. 24-32. (In Russ.)

16. Melnik, M. V. \& Kogdenko, V. G. (2007) Economic analysis in audit. Moscow, UNITI-DANA Publ. (In Russ.)

17. Plaskova, N. S. (2009) Strategic economic analysis of business performance. Moscow. Russian St. Univ. of Trade and Economics Publ. (In Russ.)

18. Prokopchuk, G. V. \& Korobeinikova, L. S. (2017) Economic analysis procurement of goods, works and services within the framework of electronic auction. Modern Economics: Problems and Solutions, 2, 26-39. (In Russ.).

19. Chupandina, E. E. \& Ivanovskaya, N. P. (2018) Information support of economic analysis of purchase of medicinal preparations. Modern Economics: Problems and Solutions, 4, 56-61. (In Russ.).

20. Endovitsky, D. A. (ed.) (2017) [Economic analysis of corporate calculations]. Voronezh. Voronezh St. Univ. Publ. (In Russ.).

21. Yakovlev, A. A., Demidova, O. A. \& Podkolzina, E. A. (2015) [An empirical analysis of public procurement systems in Russia]. Moscow. HSE Publ. (In Russ.).
Larisa S. Korobeinikova, Cand. Sci. (Econ.), Assoc. Prof., Head of Economic Analysis and $\mathrm{Au}-$ dit Department, Voronezh State University, Voronezh, Russian Federation

E-mail: korobeinikova@vsu.ru

ORCID ID: 0000-0003-4290-9880
Received 20.04.2020

Accepted 13.05.2020 